\title{
Liability of physicans and dentists - key issues
}

\begin{abstract}
Physicians and dentists can be held liable for commissions and omissions relating to the exercise of medical activity. Medical liability involves the obligation to redress the damage (harm) which occurred as a result of acts or omissions committed in the course of medical activity. Whether liability will arise depends on the occurrence of damage which stands in an adequate causal relationship to the event provided for in applicable regulations. This event may be non-performance or improper performance of a contract for the provision of medical services (contractual liability) or unlawful and culpable conduct in the exercise of medical action taken toward the patient who is not bound to the doctor by a legal relationship (tort liability). When a physician or a dentist is assigned a liability, he/she is obliged to redress the pecuniary damage and compensate for the non-pecuniary injury (wrong) suffered by the injured party.
\end{abstract}

Keywords: physicians, dentists, malpractice, liability, damage, indemnity, compensation.

DOI: $10.1515 /$ pjph-2016-0032

\section{Preliminary remarks}

The liability of doctors and dentists for commissions and omissions relating to the exercise of medical activity is a complex and multi-threaded problem (according to Art. 3, Section 1 of the Medical Activity Act of 15 April 2011, Journal of Laws 2015, Item. 618, consolidated text, medical activity is the provision of health services, understood as actions aimed at preserving, saving, restoring or improving health, and other medical activities resulting from the treatment process or from separate regulations providing for rules on their execution). Medical practitioners can be held liable for criminal, professional, employee and civil charges [1, p. 101]. Each of these liability regimes is subject to regulation by different legal acts.

Civil liability of physicians and dentists is governed, in particular, by the provisions of the Civil Code. This type of liability involves the obligation to compensate for damage arising from wrongful acts and omissions during the exercise of medical activity. The provisions of the Civil Code define types of this liability, its conditions and principles.

\section{Types of medical malpractice liability}

The civil law distinguishes types of liability for damages by making reference to the type of event, which is one of the conditions for establishing liability. In reference to the rules developed in Roman law, a distinction is made between contractual liability (ex contractu) and tort liability (ex delicto). In the case of the former, the obligation to redress the damage results from non-performance or improper performance of an obligation that existed between the parties (Art. 471 of the Polish Civil Code (CC) et seq) [2, pp. 54-55], [3, pp. 85-86]
[4, p. 85]. Tort liability, in turn, arises regardless of the legal bond between the parties, as a result of the occurrence of a civil wrong (a tort), defined as the unlawful conduct of a legal entity [2, p. 54-55], [3, p. 85-86], [4, pp. 85]. In the case of medical and dental practitioners, contractual liability arises in the event of failure to perform or improper performance of duties related to the provision of health services, resulting from a previously established obligation, which usually has its origin in a contract concluded with the patient or made in favour of the patient. Tort liability, on the other hand, is a consequence of a physician or dentist engaging in unlawful (contrary to the law, the rules of social conduct, the principles of professional ethics) and culpable conduct during the provision of health services $[5$, p. 66]. Tort liability may, therefore, arise independent of whether a contract has been concluded with the patient or not. It cannot be ruled out that one and the same event will be interpreted both as a manifestation of nonperformance or improper performance of an obligation undertaken by the doctor in relation to the patient, and a civil wrong (a tort) (for example, an injury to the body which occurred as a result of a medical procedure improperly performed by a doctor who had previously entered into a contract for the provision of a medical service [6, p. 1489]). In such circumstances, there is a joinder of claims by the plaintiff. Interpretation of Article 443 of the Civil Code leads to the conclusion that, in principle, in cases of a joinder of claims ex contractu and ex delicto, the injured is entitled to choose the grounds for seeking indemnity. Freedom of choice is excluded when so provided by the Act or when stipulated so in the contract [2, p. 183], [3, p. 288], [7, p. 886].

${ }^{1}$ Department of Civil Law, Maria Curie-Skłodowska University in Lublin, Poland

${ }^{2}$ Chair and Department of Pedodontics, Medical University in Lublin, Poland 


\section{Conditions of medical malpractice liability}

Under current legislation, there are three conditions for liability in damages, which, when jointly satisfied, give rise to the obligation to redress the damage. They include the occurrence of damage, the occurrence of an event (fact) which the provision of the Act recognizes as giving rise to the obligation attributed to a designated entity to redress the damage (the damaging event), and the relationship between the occurrence of damage and the above-described event [2, p. 54], [4, p. 82] [8].

\section{The occurrence of damage}

The Civil Code does not define the term damage. The doctrine assumes that damage, sensu largo, is any kind of loss which the subject suffers against his/her will in relation to an interest protected by law, whether pecuniary or non-pecuniary [2, p. 62], [3, p. 88], [4, p. 90]. With respect to the type of legally protected interest that has been injured, a distinction is made between property damage, involving injury to the property of the injured party (e.g. damage to a thing), and personal injury which affects directly the personal interest of the injured (e.g. causing bodily harm, causing damage to health, infringing personal dignity). It should be emphasized that personal injury may involve two types of loss: pecuniary (e.g. expenses on treatment and rehabilitation, loss of income) and non-pecuniary (e.g. physical pain, negative psychological experiences). What arises in the first of these situations is pecuniary injury (damage sensu stricto, referred to in short as damage), in the second, a wrong is done. Damage may be done directly to the patient or indirectly, in connection with the patient's death, to other persons (usually his/her relatives or persons to whom the patient was under an obligation to pay alimony).

It cannot be ruled out that the conduct of a doctor or a dentist associated with the provision of health services will result in damage to property and, as a consequence, to pecuniary loss (pecuniary injury, damage sensu stricto). In medical practice, there sometimes occur factual circumstances in which damage is done to the patient's clothing and/or personal items, especially when a doctor is forced to take rapid action in situations posing an immediate threat to life. More important, however, are those cases in which the grounds for liability of a doctor or a dentist are provided by a personal injury. The liability for the consequences of infringement upon personal interest of the injured is an obligation to compensate for the pecuniary and non-pecuniary losses sustained as a result of the infringement. Depending on whether the loss is pecuniary or nonpecuniary, the liable physician or dentist is obliged to pay damages or redress the wrong. The injured is entitled to make relevant claims, and in the case of his/her death, so are also other persons (the so-called indirectly injured).

\section{The damaging event}

Depending on the type of liability, an event with which the law associates the obligation of a physician or a dentist to redress the damage may be a failure to perform or improper performance of an obligation existing between the physician and the injured patient or a tort involving illegal conduct on the part of the doctor (see also earlier comments on joinder of claims).

The obligation existing between the physician or dentist performing health services and the patient, in a typical situation, follows from an agreement referred to as a contract for the provision of medical (health) services, which pursuant to
Article $750 \mathrm{CC}$, is regulated by the provisions on mandate (Art. 734 CC et seq.) [5, p. 69], [9, p. 66], [10, p. 399]. Such an agreement is concluded between the patient and a physician or a dentist who runs a private office (performs individual medical practice or individual specialist medical practice). The doctor who is carrying out a contract for the provision of medical services operates on the basis and within the boundaries of consent given by the patient (and in special situations, his/her legal representative, actual guardian or guardianship court).

It has to be considered what conduct of the physician or dentist who is bound with the patient by a contract for the provision of medical services can be considered a manifestation of non-performance or improper performance of the obligation, giving rise to the obligation to redress the damage. To do this, a reference has to be made to the division of obligations into obligations of result and obligations of due diligence. The former are considered to be satisfied when, as a consequence of a specific conduct of the debtor, a predetermined goal (result), defined as a discernible change in the external circumstances, is achieved. Obligations of due diligence, on the other hand, are considered to have been duly performed if the debtor behaves, with due diligence, in a manner consistent with the content of the obligation (e.g. teaches another person a foreign language) without being obliged to achieve any result as a consequence of his/her conduct. In legal science, arguments are put forward that certain obligations arising from contracts for the provision of medical services should be classified as obligations of result. This relates in particular to the services provided by dentists (tooth extraction, construction and insertion of a fixed prosthetic, implantation), but also medical doctors (X-ray testing and providing a report on the findings, removing a stigma, surgical correction of the nasal cartilages, breast augmentation with silicone implants) [1, p. 205], [5, p. 75], [9, p. 54]. More convincing, however, is the recognition of the obligation in question as an obligation of due diligence $[5$, p. 77$],[9$, p. 56], [11, p. 21]. It is an obligation of medical and dental practitioners to exercise due diligence in providing appropriate medical consultations, performing therapeutic procedures, providing care to patients, etc. Engaging in such conduct may, but need not (due to unforeseeable circumstances, in particular the patient's individual characteristics) lead to a certain expected result, and, therefore, the achievement of the result should not be treated as a doctor's duty [5, p. 82].

Interpretation of the provisions of Articles 471, 472 and 474 $\mathrm{CC}$ leads to the conclusion that a physician and a dentist have an obligation to redress a damage caused by non-performance or improper performance of a contract for the provision of medical services only in cases in which the damage is a consequence of a wrongful act or omission by the medical practitioner or the persons who have helped him/her carry out the contract [10, p. 418]. The medical practitioner who is providing medical services under a contract concluded with a patient is, therefore, liable for culpable conduct of persons with the assistance of whom he/she performs the contract or the persons whom he/she authorizes to carry out the contract in his stead. The said conduct includes activities carried out by other doctors (e.g. specialist consultations, written radiology reports on X-rays, anaesthesia), laboratory diagnosticians (e.g. analysis of the physical, chemical and biological properties of body fluids, excretions and secretions of patients, microbiological testing), and technicians (e.g. fabrication of dental restorations 
and removable orthodontic appliances). This liability is independent of the doctor's own fault.

A similar interpretation is applied to those cases in which a medical or dental practitioner voluntarily provides medical service without having concluded a contract, e.g. to an unconscious person, a person injured in an accident, etc. [9, p. 60]. The practitioner is treated as managing somebody else's affairs without mandate (Art. $752 \mathrm{CC}$ et seq). He/she is thus liable for culpable non-performance or improper performance of an obligation [5, p. 73].

Cases of events giving rise to damage in connection with the provision of health services other than those described above are regarded as tortious acts (delicts). In particular, events that may give rise to liability in tort of a medical or dental practitioner include a wrongful act or omission in providing medical services, when the doctor is not party to a contract with the patient (if the patient has entered into a contract with a health care facility); acting without the patient's consent or outside the scope of the patient's consent; conducting an experiment; using treatment which raises risk of harm disproportionately greater than the expected benefits; refusing to provide assistance despite the obligation to do so [9, p. 73].

The Civil Code knows three principles of tort liability, which explain the sense of attributing liability for damage to a particular entity. These are the principle of fault (referred to as the fundamental principle), the principle of risk and the principle of equity [3, pp. 21-212]. A physician or a dentist is usually assigned liability for damage based on the principle of fault. A doctor, therefore, is held liable insofar as his/her conduct is culpable [12].

The concept of fault is not defined by the provisions of the Civil Code. Traditionally, it is assumed that a fault occurs when the tortfeasor can be charged with objectively and subjectively inappropriate conduct [3, p. 215], [4, p. 192], [8]. The objective element of fault, traditionally referred to as unlawfulness, is deviation of the tortfeasor's conduct from the law or the rules of social coexistence [3, p. 215], [4, p. 192-193]. When damage is done by a physician or a dentist, the objective element of fault will be violation by the doctor of regulations (e.g. a failure to obtain the required consent of the patient), rules of professional ethics (engaging in conduct contrary to the Code of Medical Ethics), and rules resulting from the principles of medical knowledge (failure to establish a diagnosis, institution of an inappropriate therapeutic regimen) and professional experience [13]. The objective element thus most commonly comes down to medical error, understood as a health provider's conduct (action or inaction) related to diagnosis and treatment which is inconsistent with medical knowledge accessible to the doctor [5, p. 84], [8] [14]. A distinction is drawn between a diagnostic error, a therapeutic mistake (a treatment error), and a prognostic error (inaccurate prognostic estimate) [14, 15]. In the doctrine, the term medical error does not extend to technical, organizational, or administrative errors (such as wrong-patient surgery, leaving a surgical tool at the surgical site, violation of aseptic principles), because these errors are not related to the application of medical knowledge (which does not mean that they cannot be called upon as grounds for liability claims) [1, pp. 87-88], [5, p. 84], [11, pp. 224-225]. The occurrence of a medical error is an objective event. Only assignment of fault for a medical error in the subjective sense can give rise to a medical or dental practitioner's liability for damage.
The subjective element of fault involves the possibility of charging the tortfeasor with having engaged in unlawful conduct despite the fact that he/she could and should have behaved differently. Subjective fault thus comes down to outside evaluation of the mental attitude of the tortfeasor towards his/ her own unlawful conduct (the normative theory of fault) $[2$, p. 57], [3, p. 218], [4, p. 196]. There are two types of subjective fault: intentional and unintentional. Intentional fault can take the form of a direct intent (the tortfeasor embarks on an unlawful course of conduct with an intent to do damage or harm) or oblique intent (the tortfeasor does not intend to do damage or harm, but foresees that damage or harm can occur, and agrees to this); unintentional fault can take the form of recklessness (the tortfeasor foresees that damage or harm may arise from his/her actions, but recklessly assumes it will not) or negligence (the tortfeasor does not foresee that damage or harm may occur, though he should do so). Tort liability of a physician or dentist does not depend on the form of fault. A medical practitioner is thus liable for any fault whether intentional or unintentional. The provision of Article $415 \mathrm{CC}$, which provides a substantive basis for attributing liability to a medical or dental practitioner based on fault, does not make the obligation to redress damage conditional on the occurrence of a particular form of fault. It seems, nevertheless, that medical fault does not apply to cases of scientific error [5, p. 84], i.e. diagnostic errors justified by the current state of medical knowledge [16], or therapeutic mistakes arising despite the doctor's having acted in accordance with the principles of medical knowledge (i.e. mistakes which arise within the limits of so-called "medical risk") $[8,17]$.

It is impossible to give an exhaustive list of specific cases of subjective medical fault. An attempt to categorize these cases has led, however, to the identification of two sets: cases of fault related to medical (health) technology (a doctor's lack of the necessary knowledge and skills, careless or unskilled performance of duties, inattention) and cases of fault unrelated to medical technology (failure to inform the patient about a procedure or treatment, their effects, and risks; refusal to perform a procedure; performing a procedure without the patient's consent; conducting an experiment which poses risk to the patient; performing a procedure whose risks outweigh the benefits).

Examples of specific events which have become grounds for liability in tort of a physician or a dentist are provided in the past rulings of courts of general jurisdiction and the Supreme Court.

In case law, it is stressed that medical errors which may provide grounds for the obligation to redress damage do not only include therapeutic mistakes (treatment errors) but also diagnostic errors. The latter may involve failure to take diagnostic steps: failure to order diagnostic tests, writing a referral for a diagnostic test or examination when there are indications for immediate diagnostic assessment, or failure to evaluate test results [18], all of which may lead to non-intervention, delayed intervention or improper therapeutic intervention [14].

For example, case law has viewed as a medical error a case of failure to exercise special postoperative supervision over a patient who had suffered uncommon complications following endoscopic-guided percutaneous nephrolithotony (PCNL) for renal stones which was terminated and completed by the classical method (lumbar incision) [19]. Due to the lack of proper postoperative supervision, there had been a delay in testing and initiating conservative treatment and, conse- 
quently, the kidney had had to be removed. There was no doubt as to whether the PCNL procedure itself had been performed correctly (the medical staff were not considered culpable for the complications that ensued during the surgery) and whether the decision to complete treatment by the classical method had been justified. An objectively inappropriate conduct in that case was the failure to perform adequate postoperative tests (an ultrasonography and a urography, which the patient finally ordered on his own initiative), despite the emergence of uncommon complications.

The courts have assessed numerous cases in which loss arose in connection with childbirth. It has been adjudicated that it is a medical error to continue to perform vaginal delivery when, at some point in the process of childbirth, there are absolute indications for caesarean section $[20,21]$. In the factual circumstances considered by the court, a pregnant woman came to hospital to deliver her baby on $15^{\text {th }}$ February at 2:20 hours. Cardiotocography (CTG) recordings (monitoring fetal heart rate and simultaneously recording uterine contractions) taken from 9:00 hours onwards on February $17^{\text {th }}$ indicated that the status of the fetus was deteriorating with time, and CTG recordings taken between 18:00-20:00 hours on the same day indicated the need for the operating staff to be ready to counteract protracted labor. The CTG traces recorded from 1 am next day (February $18^{\text {th }}$ ) were pathological and that was a indications for surgical resolution of the pregnancy by prompt caesarean section. Despite these circumstances, the labor ended with vaginal delivery at 3:35 hours. As a consequence of the way the delivery was handled, the fetus was deprived of an adequate supply of oxygen for two hours, suffering from hypoxia, which resulted in severe perinatal hypoxic-ischemic encephalopathy and cerebral palsy [20].

Another court ruling has established as a medical error the fact of surgeons having operated a patient's right hip, in which there were no lesions, instead of the left hip [22]. The court dismissed the defendant's plea that due to the nature of the disease, the patient's right hip would have to undergo surgery anyway, if not immediately, then in the nearest future. The Court adjudicated that subjecting the patient to a medically unnecessary procedure provided legal grounds for redressing the damage.

The courts have also voiced their opinion on the unlawfulness of a medical procedure performed despite the lack of the patient's consent or despite the consent being defective. It has been emphasized that the unlawfulness of a physician's or a dentist's conduct leading to personal injury can only be precluded by informed consent [8, 23-28]. A patient's declaration bears the features of "informed" consent when, before it is given, the doctor advises the patient about the consequences of the therapeutic procedure to be performed, and the patient knows and understands what he is agreeing to and what, in particular, what complications, can be expected [8, 23, 24]. At the same time, the fear that the patient will not consent to treatment cannot be a justification for insufficiently informing the patient about the possible complications [24]. Also, performing a procedure in accordance with the principles of medical science but without the patient's consent, is considered to be an unlawful act [25].

\section{The relationship between the occurrence of damage and the damaging event}

The damage and the event leading to the liability for damages must remain in a causal relationship. Otherwise, liability for damages of a medical or dental practitioner does not arise. The Supreme Court, in a case under file number IV CKN 168/01 examined factual circumstances in which, in accordance with the Court's findings, a thyroidectomy, performed with all due diligence and care, had caused permanent disability (paralysis) of the patient's right vocal fold. The plaintiff set forth that, before giving her consent to the surgery, she had only been informed about ordinary, common and normally occurring sequelae of such treatment, which do not include impairment (paralysis) of a vocal fold (it affects 3-5\% of patients). The court found, however, that because the operation was a health-saving procedure, the failure to provide information about the uncommon consequences of the surgery could not have constituted a circumstance determining the plaintiff's refusal to undergo treatment. Thus, the Court established that there was no causal link between the lack of comprehensive information on all the possible consequences of the procedure and the damage which had occurred [29].

The existence of a causal link is established by performing a conditio sine qua non test, which allows the court to conclude that a specific event was the cause of the damage [2, p. 61], [4, p. 88]. The Civil Code adopts the concept of an adequate causal connection [2, p. 61], [3, p. 223, 225], [4, p. 87]. A medical practitioner who is held liable is obliged to redress the damage which is a normal consequence of the causal event (Art. 361 $\S 1 \mathrm{CC})$.

It should be emphasized that the adequacy of a causal connection does not presuppose that this relationship must be direct [11, pp. 249-250], [30, pp. 142-143], [31]. In a judgment of 17 June 2009, the Court considered whether there was an adequate causal connection between a tardy diagnosis of cerebral palsy and epilepsy in a minor plaintiff, and the diminished chances of improving his health. The doctor's conduct had not been, in the Court's opinion, the direct cause of the deterioration of the plaintiff's health (in the sense that there were no other elements in the chain of events leading from the doctor's conduct to the deterioration of the patient's health). However, the failure to take diagnostic steps and the tardy diagnosis which was the consequence of this failure led to delayed rehabilitation, thus diminishing the chances of recovery. Accordingly, the Court ruled that there was an adequate causal connection between the conduct of the doctor who had failed to perform an appropriate examination and order appropriate tests, and the damage which had arisen [32].

Pursuant to Art. $6 \mathrm{CC}$, it is the plaintiff who should prove the existence of an adequate causal link between the unlawful and culpable conduct of a physician or dentist, and the occurrence of damage. In doctrine and case law, however, there is unanimous agreement that in so-called "medical malpractice cases" proof of such causality need not be established to a certainty [5, p. 95-96], [9, p. 111-112], [11, p. 251], [33], [34], [35]. This is because the relationships existing in medicine cannot be reduced to a simple dependence where one phenomenon implies another [34]. It is, then, impossible to establish with absolute certainty the existence of a causal link between a doctor's conduct and the occurrence of damage. The same applies to establishing whether the conduct of a doctor was the sole cause of damage [33]. Causality is considered to have 
been established if there is a high degree of probability that a doctor's unlawful and culpable conduct was the cause of the damage.

\section{Compensation regimes}

Compensation for damage is meant to remedy the loss sustained by the injured person to his/her legally protected interest. The injured party can receive only one compensation, even in cases where the same event can be considered as a non-performance (improper performance) of an obligation and a tortious act. It is not therefore the function of liability to provide the injured with additional benefits exceeding the amount of sustained damage or to punish the person liable for damages. This is reflected in the provisions of the Civil Code. According to Art. $361 \S 2 \mathrm{CC}$, damages are awarded for the loss which the injured suffered (damnum emergens) and the expected gain or profits that he/she could have made but for the damage (lucrum cessans).

According to the Civil Code, compensation is provided by restoring the previous condition (natural restitution) or by payment of an appropriate sum of money, the amount of which is fixed according to the prices on the date the damages are determined (Art. $363 \mathrm{CC}$ ). The injured party is entitled to choose the form of compensation, but in cases where restitution is impossible or would cause excessive difficulties or costs to the liable party, only pecuniary compensation involving payment of an appropriate sum of money can be demanded (Art. $361 \S$ 1 in fine $\mathrm{CC}$ ).

The amount of pecuniary compensation (and thus the amount of damages) is determined using the differential method. In brief, it consists in comparing the plaintiff's economic standing before and after the event and determining the difference that the occurrence of the event caused [2, pp. 65-66], [3, p. 288], [4, p. 93] .

In particular, the Civil Code regulates the form of compensation for losses resulting from personal injury, both pecuniary (damage sensu stricto) and non-pecuniary (a wrong).

First, the Civil Code regulates the form of compensation for personal pecuniary injury (damage sensu stricto) in relation to the directly injured party (special damages). Pursuant to Art. $444 \S 1 \mathrm{CC}$, in the event of a bodily injury or damage to health, the injured party may demand the payment of all costs resulting therefrom. Compensation thus covers the costs of treatment, rehabilitation, care, diet, nursing care, travel expenses incurred by relatives, supply of necessary equipment (appliances, apparatuses, prostheses, glasses, etc.), loss of earnings, and/or costs of learning a new profession. In addition to singlepayment of compensation for the damage, the injured party may demand to be paid an annuity if the injury has caused total or partial loss of his/her ability to work or increased his/ her needs or diminished his/her future prospects (Art. 444 § $2 \mathrm{CC}$ ). A person who is obliged to redress the damage, in the event of the death of the injured person shall be liable to third parties. He/she is obliged to reimburse the medical expenses and funeral expenses of the directly injured party to the person who incurred them (Art. $446 \S 1$ CC). Moreover, a person towards whom the patient was under a maintenance (alimony) obligation, may demand a pension (an annuity) to be paid for a period of the likely duration of the maintenance obligation. The amount of the annuity will depend on the plaintiff's needs and the income and assets of the deceased. This type of annuity is called mandatory annuity [2, p. 174], [4, p. 257-258].
Other family members of the deceased, to whom he/she voluntarily and permanently provided livelihood, can demand an optional annuity, if the granting of such an annuity is justified by the principles of social coexistence (Art. 446 \& 1 CC). Immediate family members of the deceased are also entitled to claim additional damages if the death of the victim resulted in a significant deterioration of their financial situation.

The provisions of the Civil Code also regulate the form of compensation for non-pecuniary loss (a wrong) caused by personal injury (general damages). As in the case of redressing a pecuniary loss, relevant claims can be made by the directly injured person (Art. 445, $448 \mathrm{CC}$ ) and in the event of his death, by the closest members of his/her family (Art. $446 \S 4 \mathrm{CC}$ ). The general provision of Art. 448 of the Civil Code stipulates that an injured person who, as a result of infringement of his/ her personal interests, suffered a non-pecuniary loss (a wrong) can demand a pecuniary compensation or a lump sum to be awarded to a social cause of his/her choosing. In the event of a bodily injury or damage to health, the injured can demand a pecuniary compensation (Art. $445 \S 1 \mathrm{CC}$, in conjunction with Art. $444 \S 1 \mathrm{CC}$ ). The amount of such compensation is determined by the court on the basis of the type, intensity and duration of the injured person's physical and mental suffering [36, p. 240].

\section{REFERENCES}

1. Fiutak A. Prawo w medycynie. Warszawa: Wydawnictwo C.H. Beck, 2011.

2. Brzozowski A, Jastrzębski J, Kaliński M, Skowrońska-Bocian E. Zobowiązania. Część ogólna. Warszawa: Wydawnictwo LexisNexis; 2013.

3. Czachórski W, Brzozowski A, Safjan M, Skowrońska-Bocian E. Zobowiązania. Zarys wykładu. Warszawa: Wydawnictwo LexisNexis; 2009.

4. Radwański Z, Olejniczak A. Zobowiązania - część ogólna. Warszawa: Wydawnictwo C.H. Beck; 2012.

5. Nesterowicz M. Prawo medyczne. Toruń: Wydawnictwo Dom Organizatora; 2010.

6. Safjan M. In: Kodeks cywilny. Komentarz. Tom I. Art. 1-449 ${ }^{10}$ (ed. K. Pietrzykowski). Warszawa: Wydawnictwo C.H. Beck; 2015.

7. Dubis W. In: Kodeks cywilny. Komentarz (ed. E. Gniewek, P. Machnikowski), Warszawa: Wydawnictwo C.H. Beck; 2014.

8. Wyrok Sądu Apelacyjnego w Warszawie z 21.01.2016 r., VI ACa 322/15, LEX nr 2004480.

9. Nesterowicz M. Kontraktowa i deliktowa odpowiedzialność lekarza za zabieg leczniczy. Warszawa-Poznań: Wydawnictwo PWN; 1972.

10. Nesterowicz M. In: System Prawa Prywatnego. Tom 9. Prawo zobowiązań - umowy nienazwane (ed. W. J. Katner). Warszawa: Wydawnictwo C.H. Beck; 2015.

11. Sośniak M. Cywilna odpowiedzialność lekarza. Warszawa: Wydawnictwo Prawnicze; 1977.

12. Wyrok Sądu Najwyższego z 18.01.2013 r., IV CSK 431/12, LEX nr 1275006.

13. Wyrok Sądu Najwyższego z 10.02.2010 r., V CSK 287/09, Orzecznictwo Sądów Polskich 2012, nr 10, poz. 95.

14. Wyrok Sądu Apelacyjnego w Łodzi z 22.12.2014 r., I ACa 903/14, LEX nr 1695104.

15. Wyrok Sądu Apelacyjnego w Szczecinie z 24.06.2015 r., I ACa 86/14, LEX nr 1798732.

16. Wyrok Sądu Najwyższego z 5.02.1974 r., I PR 518/73, LEX nr 1289095.

17. Wyrok Sądu Apelacyjnego w Białymstoku z 9.03.2016 r., I ACa 817/15, LEX nr 2016283.

18. Wyrok Sądu Apelacyjnego w Warszawie z 27.06.2007 r., VI ACa 108/07, Orzecznictwo Sądów Apelacyjnych 2009, nr 5, poz. 5.

19. Wyrok Sądu Apelacyjnego w Lublinie z 4.03.2009 r., I ACa 12/09, LEX nr 845994.

20. Wyrok Sądu Apelacyjnego w Lublinie z 10.01.2002 r., I ACa 576/01, Orzecznictwo Sądów Polskich 2003, nr 2, poz. 23. 
21. Wyrok Sadu Apelacyjnego w Lublinie z 21.02.2006 r., I ACa 69/06, LEX nr 321405 .

22. Wyrok Sądu Okręgowego w Lublinie z 1.02.2006 r., I C 213/04, LEX nr 532968.

23. Wyrok Sąu Apelacyjnego w Lublinie z 2.10.2003 r., I ACa 368/03, LEX nr 1681154

24. Wyrok Sądu Apelacyjnego w Lublinie z 2.10.2003 r., I ACa 369/03, LEX nr 155067.

25. Wyrok Sądu Apelacyjnego w Warszawie z 31.03.2006 r., VI ACa 973/05, LEX nr 252827.

26. Wyrok Sądu Apelacyjnego w Krakowie z 12.10.2007 r., I ACa 920/07, LEX nr 570272.

27. Wyrok Sądu Najwyższego z 16.05.2012 r., III CSK 227/11, Orzecznictwo Sadu Najwyższego Izba Cywilna - Zbiór Dodatkowy 2013, nr 1, poz. 23.

28. Wyrok Sądu Apelacyjnego w Warszawie z 21.01.2016 r., VI ACa 322/15, LEX nr 2004480.
29. Wyrok Sądu Najwyższego z 21.05.2003 r., IV CKN 168/01, LEX nr 371779

30. Nesterowicz M: Prawo medyczne. Komentarze i glosy do orzeczeń sądowych, Wydawnictwo LexisNexis: Warszawa; 2014.

31. Wyrok Sadu Apelacyjnego w Warszawie z 13.05.2015 r., I ACa 1059/14, LEX nr 1762072.

32. Wyrok Sądu Najwyższego z 17.06.2009 r., IV CSK 37/09, Orzecznictwo Sądów Polskich 2010r., nr 9, poz. 93.

33. Wyrok Sądu Apelacyjnego w Łodzi z 20.04.2015 r. I ACa 1752/14, LEX nr 1733726.

34. Wyrok Sądu Apelacyjnego w Warszawie z 13.05.2015 r., I ACa 1059/14, LEX nr 1762072.

35. Wyrok Sądu Apelacyjnego w Katowicach z 16.06.2016 r., V ACa 723/15, LEX nr 2081572.

36. Witczak H, Witczak W: W sprawie zadośćuczynienia należnego pacjentom, Teka Komisji Prawniczej - OL PAN 2010, nr III.

\section{Corresponding author}

Michał Zalewski

Department of Civil Law, Maria Curie-Skłodowska University in Lublin

Maria-Curie Skłodowska 5 Sq, 20-031 Lublin

E-mail: michal.zalewski@poczta.umcs.lublin.pl 